Article

\title{
Launch of Sustainable Plastic Apparel: Effects of Brand Luxury and Experience on Consumer Behaviour
}

\author{
Ken Kumagai ${ }^{1, *}$ and Shin'ya Nagasawa ${ }^{2}$ \\ 1 Institute for Business and Finance, Waseda University, Tokyo 169-8050, Japan \\ 2 Graduate School of Business and Finance, Waseda University, Tokyo 169-8050, Japan; nagasawa@waseda.jp \\ * Correspondence: kumagai4575@gmail.com
}

Received: 21 July 2020; Accepted: 14 September 2020; Published: 16 September 2020

check for updates

\begin{abstract}
Since plastic waste is a serious social issue, fashion companies are attempting to develop sustainable apparel made from post-consumer plastic bottles. This social issue is relevant to every company regardless of the level of brand luxury. However, previous literature has not examined the effect of this sustainable product type on consumer behaviour, whereas comprehensive sustainable development is widely discussed in luxury branding research. Consequently, this study investigates how the launch of sustainable plastic apparel affects consumer brand attitude and purchase intention. According to the 440 samples collected via an online survey in Japan, moderated mediation analyses reveal that the launch of sustainable plastic apparel positively affects brand attitude contributing to purchase intention indirectly, while it also contributes to purchase intention directly. In addition, brand luxury and brand experience are found to weaken the effect of this sustainable product launch, whereas the influence of sustainable product experience is insignificant. To launch this type of sustainable apparel effectively, luxury companies are advised to redesign their current marketing to promote sustainable products more effectively and adjust their branding tactics to align with sustainability. Otherwise, their brand luxury may lead to a disadvantage, since plastic recycling is increasingly becoming a social requirement.
\end{abstract}

Keywords: sustainability; luxury; brand experience; plastic recycling; plastic apparel; elaboration likelihood model

\section{Introduction}

In terms of plastic pollution, which has become an increasingly serious issue, the negative impact of post-consumer plastic bottles has been frequently reported [1,2], since it is a prominent environmental and social issue. Plastic bottles are typically made of polyethylene terephthalate, which is the same material used in polyester fibre for making apparel. Therefore, post-consumer bottles can be recycled into plastic materials for the production of polyester apparel [3]. Accordingly, numerous apparel companies are attempting to develop sustainable plastic apparel made from post-consumer bottles (hereafter simply referred to as 'sustainable plastic apparel') [4-6]. By launching this type of product, they can contribute to reducing plastic pollution. Moreover, modern consumers are assumed to raise their brand evaluation based on a company's sustainable practices, since they seem to be environmentally conscious [7].

Environmental pollution is a social problem relevant to every business field. Not only apparel brands for the masses, but also luxury brands face this issue. Luxury managers have been approaching the issue of sustainable development in various ways [8-10]. According to the empirical literature, green supply chains, such as green purchasing and green manufacturing, contribute to overall enterprise performance while improving the environment [11-13]. Therefore, it seems that sustainable 
operation can be meaningful from both the environmental and commercial perspectives. Even in the luxury sector, sustainable operation appears to be favourable for general consumers in a broad sense $[10,14]$. However, despite recent developments regarding sustainable plastic apparel, few studies have discussed its effect on consumer behaviour. When focusing on luxury brands' attributes, such as prestige, excellent quality, and hedonism [15-17], consumers may perceive a contradiction in terms of luxury brands and this product type made from post-consumer bottles, which is a kind of waste.

In addition, major food companies are switching their packaging material from virgin plastic made from petroleum to sustainable materials made from post-consumer bottles $[18,19]$, since they are socially responsible for this type of plastic waste. These drink containers were originally produced for the food industry. As a result, the supply/demand balance of post-consumer bottles has tightened, and their recent market price is higher than before $[20,21]$. Accordingly, the production cost of sustainable plastic apparel is estimated to be higher than that of regular plastic apparel (personal communication with $\mathrm{Mr}$. Makoto Kuroda, a manager on the sustainable development team, Mitsubishi Corporation).

According to the elaboration likelihood model (ELM), persuasive communication is expected to strongly influence consumer attitude if they have a high level of information processing ability [22-24]. From this perspective, it is likely that a consumer's brand evaluation is guided by brand communication about sustainable plastic apparel, especially when they already have product brand knowledge based on their experiences. However, in the literature, there is a lack of discussion on the relationships between product/brand experience, brand evaluation, and sustainable development.

Consequently, this study seeks to determine how consumers evaluate an apparel brand according to its luxury level when the brand launches sustainable plastic apparel made from post-consumer bottles. Consumers' brand evaluation may change according to their product/brand experience; hence, apparel brand managers need to consider these elements when building their marketing strategy. Moreover, consumers' purchase of sustainable products does not always correspond to their attitude [25]. These uncertain factors may damage an apparel company's profits, since sustainable plastics have become more expensive. By contrast, if these factors are managed appropriately, a company is assumed to contribute to environmental issues more effectively.

Accordingly, this study examines the effect of the launch of sustainable plastic apparel on consumers' brand attitude and purchase intention towards this product. In addition, it discusses how brand luxury moderates the effect of this product's launch. The influence of consumer experience on apparel brands and of this product type on attitude formation is also discussed. The purpose is to derive the strategic implications for luxury brand managers attempting to develop sustainable plastic apparel made from post-consumer bottles. The study is also relevant from an academic perspective because the effect of this product type has rarely been discussed in previous literature.

\section{Theoretical Background}

\subsection{Sustainability, Brand Attitude, and Purchase Intention}

As numerous environmental issues are frequently reported nowadays, consumers seem to be increasingly interested in sustainable products [7]. The literature suggests that sustainable factors, such as a product's environmentally friendly and ethical attributes, contribute to consumers' product evaluation [26,27]. From the perspective of supply chain management, previous empirical studies report that interactive sustainable operations between supply chain members, including both upstream and downstream companies, comprehensively generate sustainable synergy [11-13]. This synergy seems to be difficult to generate without consumers' positive reactions. It is, therefore, likely that consumer brand attitude generally becomes favourable when an apparel brand launches a sustainable product. In addition, once brand attitude rises, purchase intentions towards this product launched by the brand are also assumed to rise [28,29].

According to the theory of planned behaviour, however, not only attitude, but also subjective norm and perceived behavioural control influence consumers' behavioural intention [30]. In addition, 
previous literature reports that both sustainability benefit and cost simultaneously impact behavioural intention [31,32]. Sustainable plastic apparel is socially desirable because it contributes to reducing environmental pollution. This desirable dimension seems to be related to subjective norm, contributing to behavioural intention. By contrast, sustainable plastic apparel based on new recycling technology is perceived as costlier than a regular product. In addition, consumers may perceive a quality risk with this new product type to some extent. These elements are considered as perceived control, inhibiting behavioural intention [30,31]. Accordingly, the launch of sustainable plastic apparel is likely to enhance purchase intention if consumers strongly perceive their social contribution. Alternatively, when consumers focus on unfavourable elements such as cost and risk, their purchase intention is considered to decrease. Consequently, the following hypotheses are proposed:

Hypothesis 1 (H1): The launch of sustainable plastic apparel contributes to brand attitude.

Hypothesis 2 (H2): Brand attitude contributes to purchase intention towards sustainable plastic apparel.

Hypothesis 3a (H3a): The launch of sustainable plastic apparel contributes to purchase intention towards sustainable plastic apparel.

Hypothesis $\mathbf{3 b}$ (H3b): The launch of sustainable plastic apparel lowers purchase intention towards sustainable plastic apparel.

\subsection{Sustainability, Brand Luxury, and Brand Attitude}

In ancient times, Egyptian Pharaohs signalled their social power by having valuable goods, such as precious jewels and gold, buried with them when they died. These exclusive valuables are typical indications of luxury [33,34]. As social systems changed, these valuables changed from exclusive goods for a limited number of families with social power to objects of conspicuous consumption. By purchasing and using these hedonic products, consumers signal their status. Previous literature reports the role of luxury brands, such as that of a source of 'status signals' and 'personal pleasure' $[16,33,35,36]$, suggesting their unique attributes, such as prestige, rarity, exclusivity, excellent quality, and hedonism $[15,16,33,37,38]$. Consequently, consumers are assumed to focus on these attributes when evaluating a luxury brand.

Therefore, consumers may be confused when a luxury brand launches this specific product type made from post-consumer bottles, a kind of plastic waste. In addition, plastic waste is generated by not only the wealthy, but also all other social classes. Drinks in plastic bottles are sold everywhere, including kiosks and discount stores. These images are dissimilar to the aforementioned attributes of luxury. Furthermore, luxury contains nuances, such as excessive consumption beyond necessities [17,39]. In this context, previous studies suggest a contradiction between luxury brands and sustainability $[8,10,40,41]$.

In fact, some studies report that consumers are gradually accepting sustainable development even in the luxury sector [10,14], since their ideal self, an element of motivation for luxury consumption [42,43], is more conscious of social welfare [44]. However, although the discussion of sustainable development is comprehensive, uncertainty remains as to whether the launch of sustainable plastic apparel specifically contributes to consumers' brand evaluation.

Based on the reasoning stated above, although sustainable development is generally favourable, consumers are likely to perceive a contradiction with sustainable apparel made from plastic bottles when evaluating a luxury brand. Consequently, this study proposes the following hypothesis:

Hypothesis 4 (H4): Brand luxury inhibits the contribution of the launch of sustainable plastic apparel to consumer brand attitude. 


\subsection{Product/Brand Experience and Information Processing}

Experiences are private events that occur in response to some stimulation [45]. From the perspective of brand management, this stimulation can be deemed as product/brand information provided through numerous brand contact points, such as advertisements, stores, purchases, and use. Based on these experiences, a consumer stores product/brand information in their memory, that is, knowledge [29], to raise their information processing ability $[23,46]$.

In this context, the ELM provides valuable implications for branding. According to the ELM, consumer attitude tends to be guided by persuasive communication when a consumer has more information processing ability; when a consumer has less processing ability, he/she tends to reference peripheral cues, that is, information that lies peripherally to the communicated object [22-24]. In the context of consumer attitude formation, Chaiken argues that the more consumers receive cogent messages in advance, the more effective the persuasive communication is [47].

More specifically, Ihtiyar et al. report that shopping experience enhances both emotional and functional values, raising customer satisfaction [48]. Jiang et al. also report that consumers' pre-consumption experience contributes to brand preference and perceived value [49]. According to them, a positive experience is likely to enhance a desirable understanding of product/brand communication. From the ELM perspective, in these cases, experiences are considered to increase consumers' positive knowledge for product/brand information processing. The ELM also suggests that personal relevance enhances the effect of persuasive communications [22-24]. Remarkably, Miller et al. demonstrate relationships between personal interest, awareness, and cognitive engagement with elaboration as well as the contribution of elaboration to consumers' attitudes [50]. These results imply that the higher the consumers' involvement, the more elaboration, contributing to attitude formation.

Since environmental sustainability is a serious issue today, consumers' involvement in sustainability is assumed to be higher than before [7]. Moreover, when consumers have experienced sustainable products, they accumulate more product knowledge and, thus, understand the brand communication more than those with fewer experiences. Meanwhile, the launch of sustainable plastic apparel discussed herein is considered a form of persuasive brand communication. Consequently, from the viewpoint of the ELM concept, the more frequent the sustainable product experience, the more the consumer understands sustainable development as a form of brand communication. Therefore, this study presents the following hypothesis:

Hypothesis 5 (H5): Sustainable product experience enhances the contribution of the launch of sustainable plastic apparel to consumer brand attitude.

Similarly, when consumers have experienced a particular apparel brand, they are assumed to accumulate brand knowledge so that they can process brand communication more easily. However, in this case, the concern is the direction of the consumer experience effect. Via brand experience, a consumer generally receives cogent brand messages, including the brand story and stylish images, thereby increasing knowledge. In this case, the consumer is likely to have mixed feelings when facing sustainable plastic apparel made from post-consumer bottles, since this waste, caused by food companies, is irrelevant to the apparel brand. In addition, the image of post-consumer bottles is different from that of stylishness. Accordingly, the assumption is that a consumer with more brand experience understands sustainable plastic apparel as an incorrect brand communication and, hence, may feel negatively towards it. Therefore, the following hypothesis is proposed:

Hypothesis 6 (H6): Brand experience inhibits the contribution of the launch of sustainable plastic apparel to consumer brand attitude. 


\subsection{Research Model}

To test the six hypotheses stated above, this study assesses the effect of the launch of sustainable plastic apparel according to the moderated mediation model illustrated in Figure 1. In this model, the independent variable is the launch of sustainable plastic apparel, the dependent variable is purchase intention towards this product, and the mediator is brand attitude. Additionally, in this model, the moderators are brand luxury, brand experience, and consumers' experiences with sustainable plastic apparel.

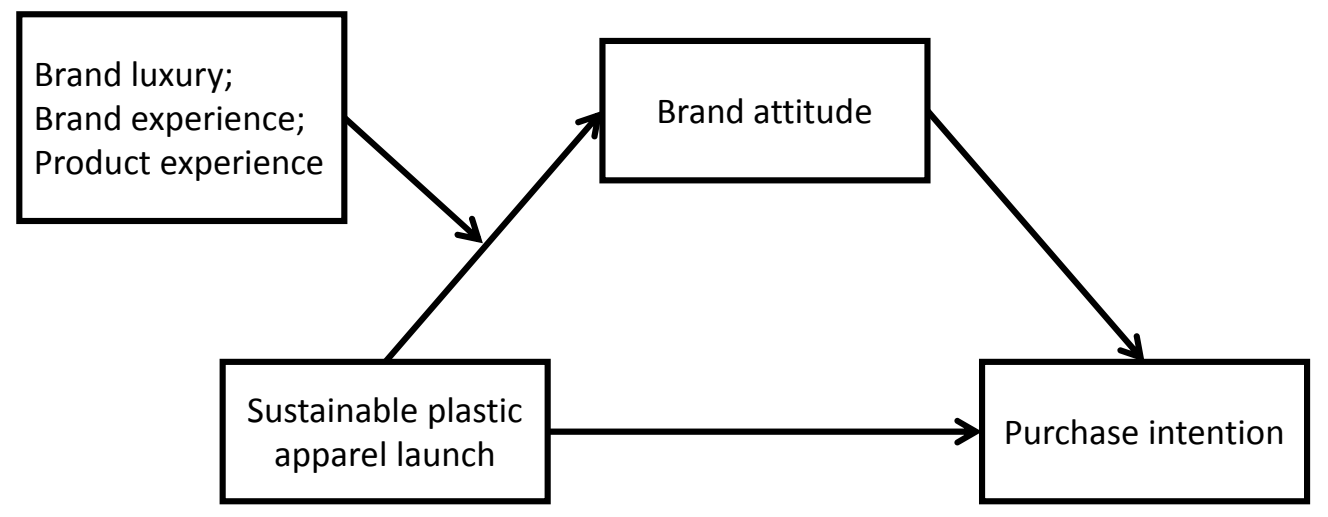

Figure 1. Research model.

Based on the model, four apparel brands, Uniqlo, Zara, Louis Vuitton, and Hermès, were evaluated in this study. Uniqlo and Zara are well-known apparel brands founded in Japan and Spain, respectively. In terms of brand value, both were ranked in the top 10 in the global apparel sector by Millward Brown [51]. Their brand luxury levels do not seem to be high, since the literature discusses both as mass brands [52,53]. Louis Vuitton and Hermès are well-known luxury brands founded in France. In terms of brand value, both were ranked in the top 10 in the global luxury sector by Millward Brown [51]. According to the literature, their luxury levels seem to be sufficiently high to consider them luxury brands [33,34]. General consumers are expected to recognise these brands and their various luxury levels; therefore, they seem to be adequate for their role as the evaluated brands in this study, in line with the research purpose.

\section{Methodology}

To examine the relationships between the launch of sustainable plastic apparel, brand luxury, consumer product/brand experience, consumer brand attitude, and purchase intention, samples were collected via an online survey in Japan. Then, the data were examined via moderated mediation analyses. The moderation effects were also examined conditionally via simple slope analyses [54-56].

In the survey, brand luxury was measured using six items from Heine and Phan [57]: high price, high quality, aesthetics, rarity, extraordinariness, and symbolism. These items were extracted as major characteristics of luxury via consumer interviews and qualitative content analyses. Brand attitude was measured using three items suggested by Adaval and Monroe [58]: attractive, desirable, and like. Bruner II reported the high consistency of these items and their validities [59]. Purchase intention was measured using three items from Bruner II: I seek out to purchase, buy if I happen to see, and I would like to try [59]. These were suggested in previous studies, including those of Baker and Churchill, Kilbourne, and Griffith and Chen [60-62]. These studies report the validity of each scale. The survey questions were assessed on a seven-point Likert-type scale ( 1 = absolutely disagree; $7=$ absolutely agree).

Consumer experience regarding evaluated brands and sustainable plastic apparel was assessed according to four experiential types: (1) reading/hearing books, articles, advertisements, websites, social networking services, and word of mouth; (2) store visit; (3) product purchase; and (4) product use. 
Following McLeod, these questions were constructed based on a five-point frequency scale $(1=$ never; 5 = always) [63]. In the survey, participants were asked about brand experience and product experience.

A regular down jacket versus a sustainable one made of recycled plastic from post-consumer bottles was set as the evaluated product. A picture of a down jacket was presented when respondents were asked about brand attitude and purchase intention. The picture was identical across brands and fabric materials in order to remove research bias caused by each respondent's design preference. Brand attitude was measured by responses to the following statements: "Brand' sells a down jacket. In this case, please tell us your feelings", and "Brand' sells a down jacket made from post-consumer bottles. In this case, please tell us your feelings."

Data were collected in collaboration with Macromill, a leading online research firm in Japan. This firm conducts not only academic research, but also governmental and business surveys. More than 10 million participants are registered with this firm in Japan [64]. The survey was conducted according to the authors' instructions. The samples were randomly collected from the pool of participants living in or around Tokyo (Tokyo, Kanagawa, Saitama, and Chiba prefectures). The population in this area represents approximately $30 \%$ of that in Japan [65-69]. In addition, this area is the key apparel market where apparel retailers, including luxury companies, operate their main retail, since the household expenditure here is approximately $1 / 3 \mathrm{rd}$ of the total household expenditure in Japan [70]. Accordingly, it is considered that consumers have brand knowledge to evaluate apparel brands. Therefore, the survey in the Tokyo area is assumed to be valid for the research purposes. Since Macromill is a member of the Japan Marketing Research Association, the data were collected in compliance with the ethical code of this institution.

The survey was first announced to each participant via the Internet. Then, they responded to the questionnaire through their personal computers or smartphones. Each question was asked in Japanese, since all respondents in this survey were Japanese general consumers in their 20s to 60s. Samples were randomly collected until there were an equal number of participants for each gender and age group using Macromill's system with a randomiser. They were then randomly assigned to one of four groups to evaluate each brand. Through the screening process, it was confirmed that all respondents knew each evaluated brand.

\section{Results}

The survey was conducted on 14-15 January, 2020, and 440 valid samples were collected (Table 1).

Table 1. Collected samples.

\begin{tabular}{cccc}
\hline Variable & & $\mathbf{n}$ & \% \\
\hline Gender & Male & 220 & $50.0 \%$ \\
& Female & 220 & $50.0 \%$ \\
\hline Age & $20-29$ & 88 & $20.0 \%$ \\
& $30-39$ & 88 & $20.0 \%$ \\
& $40-49$ & 88 & $20.0 \%$ \\
& $50-59$ & 88 & $20.0 \%$ \\
Household Income & $60-69$ & 88 & $20.0 \%$ \\
(Million Yen) & $<2.0$ & 32 & $7.3 \%$ \\
& $2.0-3.9$ & 90 & $20.5 \%$ \\
& $4.0-5.9$ & 106 & $24.1 \%$ \\
& $6.0-7.9$ & 79 & $18.0 \%$ \\
& $8.0-9.9$ & 56 & $12.7 \%$ \\
& $10.0-11.9$ & 41 & $9.3 \%$ \\
& $12.0-14.9$ & 17 & $3.9 \%$ \\
& $15.0-19.9$ & 12 & $2.7 \%$ \\
& $20.0+$ & 7 & $1.6 \%$ \\
\hline
\end{tabular}


First, based on the data, the 20 measurement items employed in the survey were examined via an exploratory factor analysis (EFA; principal factor analysis with varimax rotation). To be precise, brand experience and product experience were newly tested; the other constructs suggested by previous studies, such as brand luxury, brand attitude, and purchase intention, were retested here. As a result, the EFA loadings of three items were found to be less than 0.700 , the ideally recommended level [71]. Accordingly, these three items were removed and an EFA with 17 items was performed again, resulting in each factor loading being from 0.757 to 0.958 . Cronbach's alpha for each construct was confirmed to be from 0.912 to 0.963 . These are sufficient levels to construct each factor [71,72] (Table 2).

Table 2. Results of exploratory factor analysis (EFA).

\begin{tabular}{|c|c|c|c|c|c|}
\hline Construct & Item & Factor Loading & Mean & SD & $\begin{array}{c}\text { Cronbach's } \\
\text { Alpha }\end{array}$ \\
\hline \multirow{5}{*}{ Brand luxury } & Rarity & 0.794 & 4.478 & 1.316 & 0.912 \\
\hline & Aesthetics & 0.848 & & & \\
\hline & Quality & 0.757 & & & \\
\hline & Extraordinariness & 0.848 & & & \\
\hline & Symbolism & 0.806 & & & \\
\hline \multirow{3}{*}{$\begin{array}{c}\text { Brand } \\
\text { experience }\end{array}$} & Store visit & 0.800 & 1.997 & 1.071 & 0.938 \\
\hline & Purchase & 0.936 & & & \\
\hline & Use & 0.878 & & & \\
\hline \multirow{3}{*}{$\begin{array}{c}\text { Product } \\
\text { experience }\end{array}$} & Store visit & 0.879 & 1.715 & 0.985 & 0.952 \\
\hline & Purchase & 0.958 & & & \\
\hline & Use & 0.936 & & & \\
\hline \multirow{3}{*}{ Brand attitude } & Favourable & 0.885 & 4.280 & 1.454 & 0.963 \\
\hline & Attractive & 0.872 & & & \\
\hline & Like & 0.822 & & & \\
\hline \multirow{3}{*}{$\begin{array}{l}\text { Purchase } \\
\text { intention }\end{array}$} & Would like to try & 0.910 & 3.284 & 1.491 & 0.957 \\
\hline & Buy if happened to see & 0.937 & & & \\
\hline & Seek out to purchase & 0.863 & & & \\
\hline
\end{tabular}

A confirmatory factor analysis (CFA) was then performed to examine the 17 questionnaire items. The CFA loading of each construct was found to be from 0.783 to 0.983 , composite reliability (CR) was from 0.914 to 0.963 , and the average variance extracted (AVE) ranged from 0.680 to 0.897 . It was also confirmed that each $\sqrt{ }$ AVE exceeded the maximum interrelated correlation, each AVE exceeded the maximum shared variance (MSV), and each CR exceeded the AVE. These measures showed a sufficient level of indicator reliability, consistency reliability, convergent validity, and discriminant validity $[71,73]$ (Table 3). Goodness-of-fit (GOF) indices were found to be as follows: $\chi^{2}=573.512, d f=109, p=0.000$, $\chi^{2} / d f=5.262, \mathrm{GFI}=0.927, \mathrm{CFI}=0.970, \mathrm{TLI}=0.962, \mathrm{RMSEA}=0.070$, and SRMR $=0.039$. Although the $\chi^{2}$ statistics seem to be insufficient, this result is not enough to test the GOF comprehensively because of its sensitivity to sample size. Meanwhile, the other indices show a sufficient GOF [71,74]. Consequently, the five constructs examined in this study are assumed to be valid for testing the relationships between elements, as illustrated in Figure 1. 
Table 3. Tests of composite reliability, convergent validity, and discriminant validity.

\begin{tabular}{cccccccccc}
\hline & MSV & AVE & CR & Max r & $\begin{array}{c}\text { Brand } \\
\text { Luxury }\end{array}$ & $\begin{array}{c}\text { Brand } \\
\text { Experience }\end{array}$ & $\begin{array}{c}\text { Product } \\
\text { Experience }\end{array}$ & $\begin{array}{c}\text { Brand } \\
\text { Attitude }\end{array}$ & $\begin{array}{c}\text { Purchase } \\
\text { Intention }\end{array}$ \\
\hline $\begin{array}{c}\text { Brand } \\
\text { luxury }\end{array}$ & 0.114 & 0.680 & 0.914 & 0.338 & $\mathbf{0 . 8 2 5}$ & & & & \\
$\begin{array}{c}\text { Brand } \\
\text { experience } \\
\text { Product }\end{array}$ & 0.138 & 0.846 & 0.943 & 0.372 & -0.245 & $\mathbf{0 . 9 2 0}$ & & & \\
experience & 0.043 & 0.871 & 0.953 & 0.208 & 0.073 & 0.159 & $\mathbf{0 . 9 3 3}$ & & \\
$\begin{array}{c}\text { Brand } \\
\text { attitude }\end{array}$ & 0.213 & 0.897 & 0.963 & 0.461 & 0.338 & 0.372 & 0.208 & $\mathbf{0 . 9 4 7}$ & \\
$\begin{array}{c}\text { Purchase } \\
\text { intention }\end{array}$ & 0.213 & 0.884 & 0.958 & 0.461 & 0.036 & 0.343 & 0.195 & 0.461 & $\mathbf{0 . 9 4 0}$ \\
\hline
\end{tabular}

Note: $\sqrt{ } \mathrm{AVE}$ (average variance extracted) is bold-face diagonal. Goodness-of-fit (GOF) of the model: $\chi^{2}=573.512$, $d f=109, p=0.000, \chi^{2} / d f=5.262, \mathrm{GFI}=0.927, \mathrm{CFI}=0.970, \mathrm{TLI}=0.962, \mathrm{RMSEA}=0.070, \mathrm{SRMR}=0.039$.

To examine potential common method bias, Harman's single-factor test was conducted based on all questionnaire items. As a result, multiple factors were extracted through a principal factor analysis without rotation. Each eigenvalue was confirmed to exceed one. Moreover, there was no factor accounting for the majority of covariance between the items. Accordingly, the research model seems to be robust to common method bias [75].

Then, the relationships among the elements were examined based on moderated mediation analyses. In the analyses, the launch of sustainable plastic apparel was coded as follows: $0=$ no launch; $1=$ launch. To reduce multicollinearity, the analyses were based on mean-centred data [54]. The analyses were conducted with regard to each moderator according to the model (Figure 1; Hayes, 2013; Model 7; Number of bootstrap samples $=2000$ ) [56]. Tables $4-6$ show the results. In addition, simple slope tests with regard to significant moderation effects were performed to estimate the conditional effects (Table 7, Figure 2). In these tests, each focal value was set as the mean value \pm 1SD [54].

Table 4. Result of moderated mediation analysis (Moderator: Brand luxury).

\begin{tabular}{|c|c|c|c|c|c|c|c|}
\hline Hypotheses & Predictor & Outcome & $\beta$ & $\beta \mathrm{SE}$ & $t$-Value & $p$-Value & Result \\
\hline $\mathrm{H} 1$ & $\begin{array}{l}\text { Sustainable } \\
\text { clothing }\end{array}$ & $\begin{array}{l}\text { Brand } \\
\text { attitude }\end{array}$ & 0.187 & 0.093 & 2.022 & $p=0.043$ & Supported \\
\hline $\mathrm{H} 4$ & $\begin{array}{l}\text { Sustainable } \\
\text { clothing } \times \\
\text { brand luxury }\end{array}$ & $\begin{array}{l}\text { Brand } \\
\text { attitude }\end{array}$ & -0.202 & 0.070 & -2.868 & $p=0.004$ & Supported \\
\hline $\begin{array}{l}\mathrm{H} 3 \mathrm{a} \\
\mathrm{H} 3 \mathrm{~b}\end{array}$ & $\begin{array}{l}\text { Sustainable } \\
\text { clothing }\end{array}$ & $\begin{array}{l}\text { Purchase } \\
\text { intention }\end{array}$ & 0.187 & 0.090 & 2.093 & $p=0.037$ & $\begin{array}{c}\text { H3a: } \\
\text { Supported } \\
\text { H3b: } \\
\text { Rejected }\end{array}$ \\
\hline $\mathrm{H} 2$ & Brand attitude & $\begin{array}{l}\text { Purchase } \\
\text { intention }\end{array}$ & 0.464 & 0.031 & 15.069 & $p<0.001$ & Supported \\
\hline
\end{tabular}

Table 5. Result of moderated mediation analysis (Moderator: Product experience).

\begin{tabular}{cccccccc}
\hline Hypotheses & Predictor & Outcome & $\boldsymbol{\beta}$ & SE $\beta$ & $t$-Value & $p$-Value & Result \\
\hline H1 & $\begin{array}{c}\text { Sustainable } \\
\text { clothing }\end{array}$ & $\begin{array}{c}\text { Brand } \\
\text { attitude }\end{array}$ & 0.187 & 0.096 & 1.950 & $p=0.052$ & Supported \\
\hline H5 & $\begin{array}{c}\text { Sustainable } \\
\text { clothing } \times \\
\text { product } \\
\text { experience }\end{array}$ & $\begin{array}{c}\text { Brand } \\
\text { attitude }\end{array}$ & 0.075 & 0.098 & 0.767 & $p=0.443$ & Rejected \\
\hline
\end{tabular}


Table 5. Cont.

\begin{tabular}{cccccccc}
\hline Hypotheses & Predictor & Outcome & $\boldsymbol{\beta}$ & SE $\beta$ & $\boldsymbol{t}$-Value & $\boldsymbol{p}$-Value & Result \\
\hline $\begin{array}{c}\mathrm{H} 3 \mathrm{a} \\
\mathrm{H} 3 \mathrm{~b}\end{array}$ & $\begin{array}{c}\text { Sustainable } \\
\text { clothing }\end{array}$ & $\begin{array}{c}\text { Purchase } \\
\text { intention }\end{array}$ & 0.187 & 0.090 & 2.093 & $p=0.037$ & $\begin{array}{c}\text { H3a: } \\
\text { H3borted } \\
\text { Rejected }\end{array}$ \\
\hline $\mathrm{H} 2$ & Brand attitude & $\begin{array}{c}\text { Purchase } \\
\text { intention }\end{array}$ & 0.464 & 0.031 & 15.069 & $p<0.001$ & Supported \\
\hline
\end{tabular}

Note: The index of moderated mediation $=0.035 ; 95 \%$ CI [ -0.056 to 0.132$]$.

Table 6. Result of moderated mediation analysis (Moderator: Brand experience).

\begin{tabular}{cccccccc}
\hline Hypotheses & Predictor & Outcome & $\boldsymbol{\beta}$ & $\mathrm{SE} \boldsymbol{\beta}$ & $\boldsymbol{t}$-Value & $p$-Value & Result \\
\hline $\mathrm{H} 1$ & $\begin{array}{c}\text { Sustainable } \\
\text { clothing }\end{array}$ & $\begin{array}{c}\text { Brand } \\
\text { attitude }\end{array}$ & 0.187 & 0.090 & 2.087 & $p=0.037$ & Supported \\
\hline $\mathrm{H} 6$ & $\begin{array}{c}\text { Sustainable } \\
\text { clothing } \times \text { brand } \\
\text { experience }\end{array}$ & $\begin{array}{c}\text { Brand } \\
\text { attitude }\end{array}$ & -0.274 & 0.084 & -3.271 & $p=0.001$ & Supported \\
\hline $\mathrm{H} 3 \mathrm{a}$ & $\begin{array}{c}\text { Sustainable } \\
\text { clothing }\end{array}$ & $\begin{array}{c}\text { Purchase } \\
\text { intention }\end{array}$ & 0.187 & 0.090 & 2.093 & $p=0.037$ & $\begin{array}{c}\text { Supported } \\
\text { H3b: } \\
\text { Rejected }\end{array}$ \\
\hline $\mathrm{H} 2$ & Brand attitude & $\begin{array}{c}\text { Purchase } \\
\text { intention }\end{array}$ & 0.464 & 0.031 & 15.069 & $p<0.001$ & Supported \\
\hline
\end{tabular}

Note: The index of moderated mediation $=-0.127 ; 95 \%$ CI [ -0.204 to -0.057$]$.

Table 7. Conditional effects of the launch of sustainable plastic apparel.

\begin{tabular}{lcccc}
\hline \multicolumn{1}{c}{ Case } & $\boldsymbol{\beta}$ & SE $\boldsymbol{\beta}$ & $\boldsymbol{t}$-Value & $\boldsymbol{p}$-Value \\
\hline High luxury & -0.078 & 0.131 & -0.598 & $p=0.550$ \\
Middle luxury & 0.187 & 0.093 & 2.023 & $p=0.043$ \\
Low luxury & 0.453 & 0.131 & 3.458 & $p<0.001$ \\
High brand experience & -0.106 & 0.127 & -0.839 & $p=0.402$ \\
Middle brand experience & 0.187 & 0.090 & 2.087 & $p=0.037$ \\
Low brand experience & 0.481 & 0.127 & 3.789 & $p<0.001$ \\
\hline
\end{tabular}

Note: Outcome variable: Consumer brand attitude $\beta$ shows the impact of a sustainable plastic apparel launch. The high/low case of the moderating factor is set as the mean value \pm 1SD [54].

The data imply that the launch of sustainable plastic apparel significantly contributes to consumer brand attitude ( $\beta=0.187, t=1.950$ to $2.087, p=0.037$ to 0.052 ). Therefore, $\mathrm{H} 1$ is supported. The results also show the significant influence of brand attitude on purchase intention, supporting $\mathrm{H} 2(\beta=0.464$, $t=15.069, p<0.001)$, and that the launch positively influences purchase intention $(\beta=0.187, t=2.093$, $p=0.037$ ). Accordingly, $\mathrm{H} 2 \mathrm{a}$ is supported, but $\mathrm{H} 2 \mathrm{~b}$ is rejected.

Regarding the moderating effects, the results show a negative interaction between brand luxury and the launch of sustainable apparel $(\beta=-0.202, t=-2.868, p=0.004)$. H4 is therefore supported. However, the interaction between sustainable product experience and sustainable apparel launch is not significant $(\beta=0.075, t=0.767, p=0.443)$. H5 is therefore rejected. Meanwhile, the results suggest a negative interaction between consumer brand experience and sustainable apparel launch, supporting H6 ( $\beta=-0.274, t=-3.271, p=0.001)$. In addition, the indices of moderated mediation are significantly negative regarding brand luxury $(-0.094 ; 95 \% \mathrm{CI}=-0.165$ to -0.023$)$ as well as brand experience $(-0.127 ; 95 \% \mathrm{CI}=-0.204$ to -0.057$)$, showing that these factors inhibit the indirect effect of sustainable product launch on purchase intention.

The results of simple slope tests regarding significant moderation effects also indicate that the launch of sustainable plastic apparel strongly contributes to brand attitude when the brand luxury level 
is low, whereas this effect of sustainable development disappears in the high luxury case. In addition, this sustainable development contributes to consumer brand attitude strongly in the case with a low brand experience level, whereas this contribution disappears in the case with a high experience level.
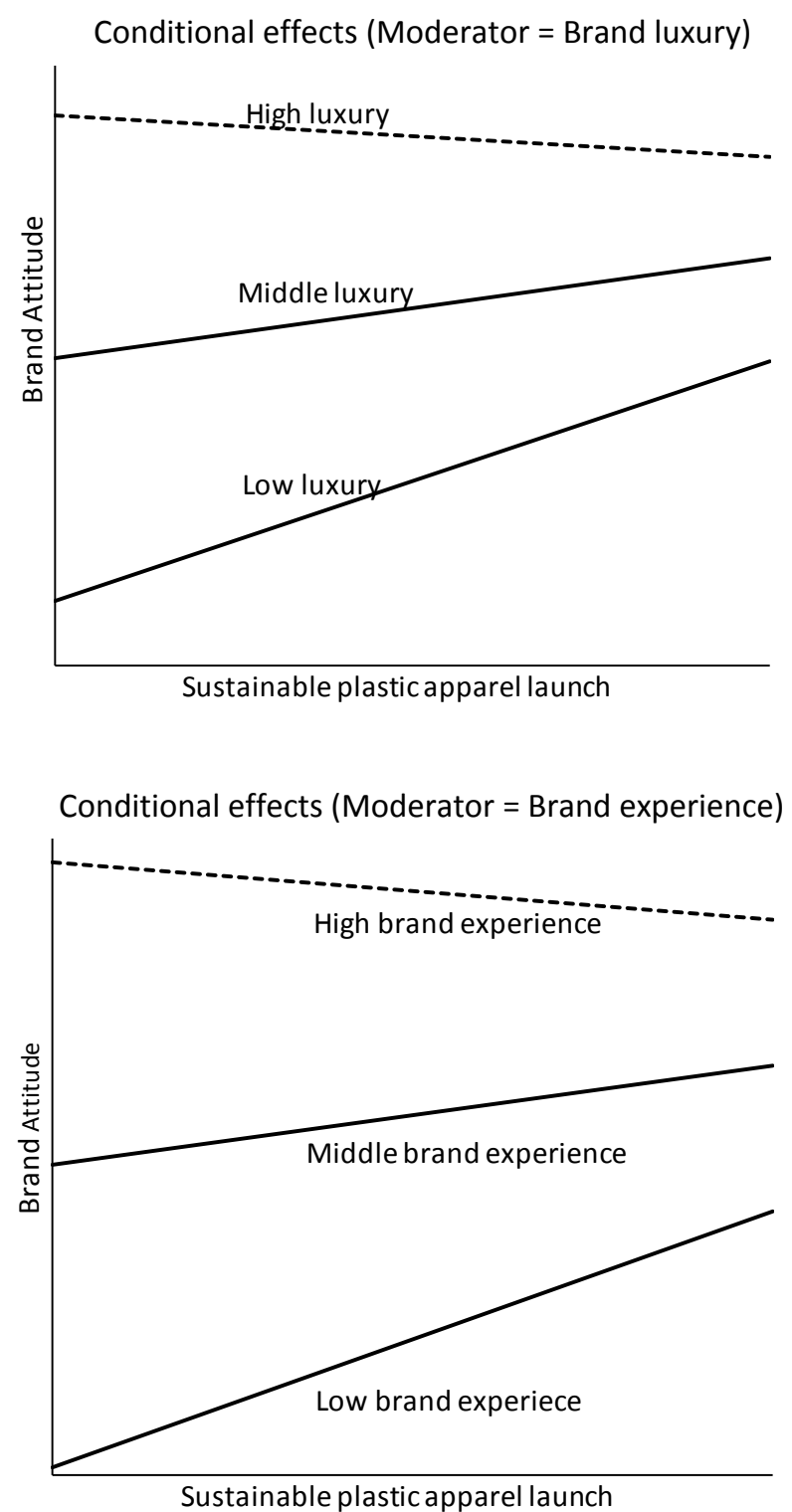

Figure 2. Simple slope tests: conditional effects of the launch of sustainable plastic apparel.

\section{Discussion and Conclusions}

As environmental issues have become a serious social concern, consumers expect every industry, including apparel companies, to contribute to sustainability. Therefore, since post-consumer bottles are a representative type of plastic waste, consumers are likely to evaluate an apparel brand favourably when it develops and launches sustainable plastic apparel made from post-consumer bottles. In addition, once brand evaluation rises, consumers seem to increase their purchase intention towards this sustainable product. This sustainable development actually reduces single-use plastic bottles.

However, the data reveal the moderating effects of brand luxury and brand experience on inhibiting the contribution of the launch of sustainable plastic apparel to consumers' brand evaluation. The results imply that consumers perceive sustainable apparel made from post-consumer bottles as contradicting the notion of brand luxury and brand image. Moreover, simple slope tests suggest that 
sustainable apparel launch may negatively impact consumers' brand evaluation when the levels of brand luxury and brand experience are high. The data imply that the contribution of sustainable product experience to consumers' brand evaluation is insignificant. This result suggests that sustainable education based on the current sustainable marketing of apparel companies is ineffective in enhancing consumers' understanding of their sustainable development practices.

The paradox is that a luxury company's efforts to increase its luxury value may counteract its own endeavours to launch sustainable plastic apparel. In addition, regardless of the brand luxury level, a company's marketing to enhance consumer brand experience may be incompatible with its sustainable efforts. However eagerly a company enhances consumer education regarding sustainable plastic apparel, this paradox will remain if its current marketing is unchanged.

Based on the results of this study, current brand image seems to be a disadvantage to apparel companies in promoting sustainable development. Companies are suggested to align their marketing with sustainability, building brand associations such as environmentally friendly and socially desirable apparel. Otherwise, brand luxury and/or current stylishness may lead to weaknesses in sustainable marketing, although sustainability is socially indispensable. As consumers are becoming increasingly sustainability-conscious, being sustainability-friendly is considered to be a key attribute of 'today's valuable brand.' Patagonia is a successful example. This California outdoor apparel company has been selling sustainable plastic apparel from the early stage of bottle recycling. It seems that Patagonia has been highly evaluated based on this sustainable clothing while keeping its favourable brand image [76,77].

According to recent empirical research, green supply chain management seems to contribute to overall enterprise performance [11-13]. Hence, we recommend that apparel companies be persistent in controlling their marketing for sustainable product image, although they may sometimes face the partial difficulty of sustainable development. The banking sector is also recommended to evaluate industrial projects related to sustainable development from the viewpoint of its overall effect on a company's operation.

The literature also reports the contribution of a sustainable supply chain at the country level: It seems to positively affect national economic indicators, such as GDP, and the natural environment. On the other hand, plastic waste is an urgent issue. Therefore, in the context of plastic recycling, governmental support, such as education on sustainability, regulation, and tax exemptions, is required. According to the empirical reports, this sustainable support does not conflict with national economic rationality $[13,78,79]$.

\section{Limitations and Future Research}

It should be noted that plastic bottles are drink containers produced for the food and beverage industry. Therefore, the primary responsibility of this plastic waste belongs to them. These companies have committed to developing a circular economy of food packages by recycling these bottles $[18,19]$. In addition, plastic bottles can be repeatedly recycled into new bottles through current technology [80], which is a type of closed loop of plastic. By contrast, it is still practically difficult to recycle plastic apparel because it contains other materials, such as colour chemicals, although new technology available for fashion waste, such as chemical recycling, has been theoretically developed [81-84]. Accordingly, the issue of plastic fashion waste remains even when companies develop sustainable apparel from post-consumer plastic bottles.

Currently, plastic bottle recycling is still insufficient [85]. Therefore, it is socially meaningful for apparel companies as well as food firms to recycle post-consumer bottles. Plastic apparel recycling is also required, especially for apparel companies, since they produce this apparel. This is the next challenge with regard to apparel companies' sustainable development and future research.

This study is based on samples collected in Japan-the literature reports differences in consumer attitudes towards environmental problems by country [86,87]. Therefore, further research across countries is necessary to generalise consumer psychology and attitude formation towards sustainable 
apparel development. In addition, the above discussion raises the question of what type of product/brand communication is appropriate for sustainable marketing of apparel companies, especially when the level of brand luxury is high. These are the main limitations of this study and the focus of our future research.

Author Contributions: Conceptualization, K.K.; methodology, K.K.; data collection, K.K.; analysis and writing, K.K.; supervision, S.N. All authors have read and agreed to the published version of the manuscript.

Funding: This research received no external funding.

Acknowledgments: This research would not have been possible without the co-operation of Macromill. The authors would like to acknowledge Makoto Kuroda for his comment regarding plastic recycling in the research.

Conflicts of Interest: The authors declare no conflict of interest.

\section{References}

1. News Corp Australia Network. We're Using a Million Plastic Bottles a Minute and Experts Warn it's a Crisis as Bad as Climate Change. Available online: https://www.news.com.au/technology/environment/ conservation/were-using-a-million-plastic-bottles-a-minute-and-experts-warn-its-a-crisis-as-bad-asclimate-change/news-story/aed4bfc5d4820312f340255841e8d6a0.2016 (accessed on 20 May 2020).

2. Parker, L. How the Plastic Bottle Went from Miracle Container to Hated Garbage. Available online: https://www.nationalgeographic.com/environment/2019/08/plastic-bottles (accessed on 20 May 2020).

3. Kumagai, K. Sustainable apparel and brand luxury. In Proceedings of the Mystique of Luxury Brands Conference, Tokyo, Japan, 20-21 September 2019; p. 16.

4. Shen, L.; Worrell, E.; Patel, M.K. Open-loop recycling: A LCA case study of PET bottle-to-fibre recycling. Resour. Conserv. Recycl. 2010, 55, 34-52. [CrossRef]

5. Sarioğlu, E.; Kaynak, H.K. PET bottle recycling for sustainable textiles. In Polyester-Production, Characterization and Innovative Applications; Camlibel, N.O., Ed.; Intech Open: London, UK, 2017; Chapter 2.

6. Onishi, T. Uniqlo and Toray Challenge to Develop Fashion Products Made from Post-Consumer Plastic Bottles and Apparel. Nikkei Business. Available online: https://business.nikkei.com/atcl/gen/19/00002/091800690 (accessed on 5 January 2020).

7. Vehmas, K.; Raudaskoski, A.; Heikkilä, P.; Harlin, A.; Mensonen, A. Consumer attitudes and communication in circular fashion. J. Fash. Mark. Manag. 2018, 22, 286-300.

8. Kapferer, J.N. All that glitters is not green: The challenge of sustainable luxury. Eur. Bus. Rev. 2010, 2, 40-45.

9. Kale, G.Ö.; Öztürk, G. The importance of sustainability in luxury brand management. Intermedia Int. Peer-Rev. E-J. Commun. Sci. 2016, 3, 106-126. [CrossRef]

10. D'Anolfo, M.; Amatulli, C.; De Angelis, M.; Pino, G. Luxury, sustainability, and corporate social responsibility: Insights from fashion luxury case studies and consumers' perceptions. In Sustainable Management of Luxury; Gardetti, M.A., Ed.; Springer: Singapore, 2017; pp. 427-448.

11. Khan, S.A.R.; Qianli, D. Impact of green supply chain management practices on firms' performance: An empirical study from the perspective of Pakistan. Environ. Sci. Pollut. Res. 2017, 24, 16829-16844.

12. Yu, Z.; Golpîra, H.; Khan, S.A.R. The impact of GSCM on manufacturing enterprise's performance. J. Adv. Manuf. Syst. 2018, 17, 445-459.

13. Khan, S.A.R.; Yu, Z. Strategic Supply Chain Management; Springer: Cham, Switzerland, 2019.

14. Ki, C.; Kim, Y.K. Sustainable luxury fashion consumption and the moderating role of guilt. Fash. Ind. Educ. 2016, 14, 18-30.

15. Dubois, B.; Laurent, G.; Czellar, S. Consumer Rapport to Luxury: Analyzing Complex and Ambivalent Attitudes; Consumer research working paper 736; HEC Paris: Jouy-en-Josas, France, 2001; Available online: https: //ideas.repec.org/p/ebg/heccah/0736.html (accessed on 10 September 2020).

16. Vigneron, F.; Johnson, L.W. Measuring perceptions of brand luxury. J. Brand Manag. 2004, 11, 484-506.

17. Kapferer, J.N.; Michaut, A. Is luxury compatible with sustainability? Luxury consumers' viewpoint. J. Brand Manag. 2014, 21, 1-22.

18. DANONE. Accelerating the Transition towards the Circular Economy, Danone Packaging Policy. 2018. Available online: https://www.danone.com/content/dam/danone-corp/danone-com/about-us-impact/ policies-and-commitments/en/2018/Danone_Packaging_Policy.pdf (accessed on 20 October 2019). 
19. Nestlé. Nestlé Aiming at $100 \%$ Recyclable or Reusable Packaging by 2025 . Available online: https://www.Nestle.com/sites/default/files/asset-library/documents/media/press-release/2018-april/ Nestlé-packaging-commitment-press-release-en.pdf (accessed on 20 October 2019).

20. Ishikawa, M. The current situation and issue of PET bottle recycling. RING 2015, 33, 2-4.

21. Nikkei. Available online: https://www.nikkei.com/article/DGKKZO57061010R20C20A3QM8000/ (accessed on 24 March 2020).

22. Petty, R.E.; Cacioppo, J.T. The elaboration likelihood model of persuasion. Adv. Exp. Soc. Psychol. 1986, 19, 123-205.

23. Petty, R.E.; Cacioppo, J.T. Attitudes and Persuasion: Classic and Contemporary Approaches; Westview Press: Oxford, UK, 1996.

24. Petty, R.E.; Briñol, P. A process approach to influencing attitudes and changing behavior: Revisiting classic findings in persuasion and popular interventions. In Sydney Symposium of Social Psychology; Applications of Social Psychology; Forgas, J.P., Crano, W.D., Fielder, K., Eds.; Routledge: London, UK, 2020.

25. Grasso, M.M.; McEnally, M.; Widdows, R.; Herr, D.G. Consumer behavior toward recycled textile products. J. Text. Inst. 2020, 91, 94-106. [CrossRef]

26. Nagasawa, S.; Tsai, P. Marketability of Environment-Conscious Product; Koyoshobo: Kyoto, Japan, 2007.

27. Niinimäki, K. Eco-clothing, consumer identity and ideology. Sustain. Dev. 2010, 18, 150-162. [CrossRef]

28. Robertson, T.S.; Kassarjian, H.H. Handbook of Consumer Behavior; Prentice Hall: Englewood Cliffs, NJ, USA, 1991.

29. Blackwell, R.D.; Miniard, P.W.; Engel, J.F. Consumer Behavior, 9th ed.; Harcourt, Inc.: Orland, CA, USA, 2001.

30. Ajzen, I. The theory of planned behavior. Organ. Behav. Hum. Decis. Process 1991, 50, 179-211. [CrossRef]

31. Hirose, Y. Determinants of environment-conscious behavior. Jpn. J. Soc. Psychol. 1994, 10, 44-55.

32. Taylor, S.; Todd, P. An integrated model of waste management behavior: A test of household recycling and composting intentions. Environ. Behav. 1995, 27, 603-630. [CrossRef]

33. Kapferer, J.N.; Bastien, M. The Luxury Strategy: Break the Rules of Marketing to Build Luxury Brands, 2nd ed.; Kogan Page Ltd.: London, UK, 2012.

34. Som, A.; Blanckaert, C. The Road to Luxury; John Wiley and Sons: Singapore, 2015.

35. Vigneron, F.; Johnson, L.W. A review and a conceptual framework of prestige-seeking consumer behavior. Acad. Mark. Sci. Rev. 1999, 1, 1-15.

36. Han, Y.J.; Nunes, J.C.; Drèze, X. Signalling status with luxury goods: The role of brand prominence. J. Mark. 2010, 74, 15-30. [CrossRef]

37. Kapferer, J.N. Why are we seduced by luxury brands? J. Brand Manag. 1998, 6, 44-49. [CrossRef]

38. Wiedmann, K.P.; Hennigs, N.; Siebels, A. Value-based segmentation of luxury consumption behavior. Psychol. Mark. 2009, 26, 625-651. [CrossRef]

39. Kapferer, J.L. Kapferer on Luxury: How Luxury Brands Can Grow Yet Remain Rare; Kogan Page: London, UK, 2015.

40. Joy, A.; Sherry, J.F., Jr.; Venkatesh, A.; Wang, J.; Chan, R. Fast fashion, sustainability, and the ethical appeal of luxury brands. Fash. Theory 2012, 16, 273-295. [CrossRef]

41. Kapferer, J.N.; Michaut, A. Luxury and sustainability: A common future? The match depends on how consumers define luxury. Lux. Res. J. 2015, 1, 3-17. [CrossRef]

42. Kumagai, K.; Nagasawa, S.Y. The influence of social self-congruity on Japanese consumers' luxury and non-luxury apparel brand attitudes. Lux. Res. J. 2016, 1, 128-149. [CrossRef]

43. Kumagai, K.; Nagasawa, S.Y. The effect of selective store location strategy and self-congruity on consumers' apparel brand attitudes toward luxury vs. non-luxury. J. Glob. Fash. Mark. 2017, 8, 266-282. [CrossRef]

44. Eirini, K.; George, P. Lust for Our Better Versions-The Meta Modern Reality's Roots and Implications. In Sustainable Management of Luxury; Gardetti, M.A., Ed.; Springer: Singapore, 2017; pp. 467-487.

45. Schmitt, B.H. Experiential Marketing; The Free Press: New York, NY, USA, 1999.

46. Aoki, Y.; Niikura, T.; Sasaki, S.; Matsushita, K. Consumer Behavior: Application to Marketing and Brand Building; Yuhikaku: Tokyo, Japan, 2012.

47. Chaiken, S. Heuristic versus systematic information processing and the use of source versus message cues in persuasion. J. Personal. Soc. Psychol. 1980, 39, 752-766. [CrossRef]

48. Ihtiyar, A.; Barut, M.; Ihtiyar, H.G. Experiential marketing, social judgements, and customer shopping experience in emerging markets. Asia Pac. J. Mark. Logist. 2019, 31, 499-515. [CrossRef] 
49. Jiang, K.; Luk, S.T.K.; Cardinali, S. The role of pre-consumption experience in perceived value of retailer brands: Consumers' experience from emerging markets. J. Bus. Res. 2018, 86, 374-385. [CrossRef]

50. Miller, Z.D.; Freimund, W.; Metcalf, E.C.; Nickerson, N.; Powell, R.B. Merging elaboration and the theory of planned behavior to understand bear spray behavior of day hikers in Yellowstone National Park. Environ. Manag. 2019, 63, 366-378. [CrossRef]

51. Millward Brown. Brand Z: Top 100 Most Valuable Global Brands 2019. Available online: http://www. millwardbrown.com/brandz/rankings-and-reports/top-global-brands/2019 (accessed on 2 November 2019).

52. Saito, T. Uniqlo Versus ZARA; Nihonkeizaishinbun-shuppansha: Tokyo, Japan, 2014.

53. Lee, C.G.; Ko, E.; Tikkanen, H.; Phan, M.C.T.; Aielo, G.; Donvito, R.; Raithel, S. Marketing mix and customer equity of SPA brands: Cross-cultural perspectives. J. Bus. Res. 2014, 67, 2155-2163. [CrossRef]

54. Cohen, J.; Cohen, P. Applied Multiple Regression/Correlation Analysis for the Behavioural Sciences, 2nd ed.; Lawrence Erlbaum Associates: Hillsdale, NJ, USA, 1893.

55. Spiller, S.A.; Fitzsimons, G.J.; Lynch, J.G., Jr.; McClelland, G.H. Spotlights, floodlights, and the magic number zero: Simple effects tests in moderated regression. J. Mark. Res. 2013, 50, 277-288. [CrossRef]

56. Hayes, A.F. Introduction to Mediation, Moderation, and Conditional Process Analysis; Guildford Publications Inc.: New York, NY, USA, 2013.

57. Heine, K.; Phan, M. Trading-up mass-market goods to luxury products. Australas. Mark. J. 2011, 19, $108-114$. [CrossRef]

58. Adaval, R.; Monroe, K.B. Automatic construction and use of contextual information for product and price evaluations. J. Consum. Res. 2002, 28, 572-588. [CrossRef]

59. Bruner, G.C., II. Marketing Scales Handbook: Top 20; GCBII Productions: Fort Worth, TX, USA, 2013.

60. Baker, M.J.; Churchill, G.A., Jr. The impact of physically attractive models on advertising evaluations. J. Mark. Res. 1977, 14, 538-555. [CrossRef]

61. Kilbourne, W.E. An exploratory study of the effect of sex role stereotyping on attitudes toward magazine advertisements. J. Acad. Mark. Sci. 1986, 14, 43-46. [CrossRef]

62. Griffith, D.A.; Chen, Q. The influence of virtual direct experience (VDE) on on-line ad message effectiveness. J. Advert. 2004, 33, 55-68. [CrossRef]

63. McLeod, S. Likert Scale Definition, Examples and Analysis. Available online: https://www.simplypsychology. org/likert-scale.html (accessed on 27 December 2019).

64. Macromil. Research Monitors; Macromill: Tokyo, Japan, 2017.

65. Tokyo Metropolitan Government. Available online: https://www.metro.tokyo.lg.jp/tosei/hodohappyo/press/ 2020/06/11/07.html (accessed on 16 June 2020).

66. Kanagawa Prefectural Government. Available online: https://www.pref.kanagawa.jp/docs/x6z/prs/r1038905. html (accessed on 16 June 2020).

67. Saitama Prefectural Government. Available online: https://www.pref.saitama.lg.jp/a0206/03suikei/geppou01. html (accessed on 16 June 2020).

68. Chiba Prefectural Government. Available online: https://www.pref.chiba.lg.jp/toukei/toukeidata/joujuu/ geppou/2020/202005.html (accessed on 16 June 2020).

69. Japanese Ministry of Internal Affairs and Communications. Population Census. Available online: https: //www.stat.go.jp/data/jinsui/new.html (accessed on 17 June 2020).

70. Japanese Cabinet Office. Annual Report on Prefectural Accounts. Available online: https://www.esri.cao.go. jp/jp/sna/data/data_list/kenmin/files/contents/main_h28.html (accessed on 17 June 2020).

71. Hair, J.F.; Black, W.C.; Babin, B.J.; Anderson, R.E. Multivariate Data Analysis, 7th ed.; Pearson Education: Harlow, UK, 2014.

72. Peterson, R.A. A meta-analysis of Cronbach's Coefficient Alpha. J. Consum. Res. 1994, 21, 381-391. [CrossRef]

73. Fornell, C.; Larcker, D.F. Evaluating Structural Equation Models with Unobservable Variables and Measurement Error. J. Mark. Res. 1981, 18, 39-50. [CrossRef]

74. Bagozzi, R.P.; Yi, Y. Specification, evaluation, and interpretation of structural equation models. J. Acad. Mark. Sci. 2012, 40, 8-34. [CrossRef]

75. Jakobsen, M.; Jensen, R. Common method bias in public management studies. Int. Public Manag. J. 2015, 8, 3-30. [CrossRef]

76. Rarick, C.A.; Feldman, L.S. Patagonia: Climbing to new highs with a smaller carbon footprint. J. Int. Acad. Case Stud. 2008, 14, 121-124. 
77. Patagonia. Recycled Polyester. Available online: https://www.patagonia.com/our-footprint/recycledpolyester.html (accessed on 3 June 2020).

78. Khan, S.A.R. The nexus between carbon emissions, poverty, economic growth, and logistics operations-empirical evidence from southeast Asian countries. Environ. Sci. Pollut. Res. 2019, 26, 13210-13220. [CrossRef] [PubMed]

79. Khan, S.A.R.; Zhang, Y.; Kumar, A.; Zavadskas, E.; Streimikiene, D. Measuring the impact of renewable energy, public health expenditure, logistics, and environmental performance on sustainable economic growth. Sustain. Dev. 2020. [CrossRef]

80. Japanese Ministry of the Environment. Business Front Runner: Recycling Bottles to Bottles. Available online: https://www.env.go.jp/policy/keizai_portal/B_industry/frontrunner/reports/h27engine16kyoeisangyo. pdf (accessed on 2 November 2019).

81. Paszun, D.; Spychaj, T. Chemical recycling of poly (ethylene terephthalate). Ind. Eng. Chem. Res. 1997, 36, 1373-1383. [CrossRef]

82. Sato, K. Chemical Recycle Technology of PET. Polymer 2003, 52, 273.

83. Toyoseikan. Available online: http://www.cjc.or.jp/commend/pdf/senshinjirei/h28/02_sys_01.pdf (accessed on 2 November 2019).

84. Jeplan. Closed Loop Technology to Make Clothes from Clothes. Available online: https://www.jeplan.co.jp/ en/technology/polyesterrecycle (accessed on 2 November 2019).

85. The Council of PET Bottle Recycling. Material Flow of PET. Available online: http://www.petbottle-rec.gr.jp/ data/materia_flow.html (accessed on 5 September 2020).

86. Takeshita, T. Energy and Environmental Consciousness: Differences between Advanced and Developing Countries. J. Inst. Nucl. Saf. Syst. 1999, 6, 78-89.

87. PWC. Global Consumer Insight Survey: Customer Experience and the Retail Market Situation in Japan. Available online: https://www.pwc.com/jp/ja/knowledge/thoughtleadership/2019/assets/pdf/consumerinsights-survey.pdf (accessed on 18 June 2020).

(C) 2020 by the authors. Licensee MDPI, Basel, Switzerland. This article is an open access article distributed under the terms and conditions of the Creative Commons Attribution (CC BY) license (http://creativecommons.org/licenses/by/4.0/). 